\title{
Breeding strategies for recurrent selection of maize
}

\author{
José Marcelo Soriano Viana ${ }^{(1)}$ \\ (1)Universidade Federal de Viçosa, Dep. de Biologia Geral, CEP 36570-000 Viçosa, MG, Brazil. E-mail: jmsviana@ufv.br
}

\begin{abstract}
The objectives of this work were to analyze theoretical genetic gains of maize due to recurrent selection among full-sib and half-sib families, obtained by Design I, Full-Sib Design and Half-Sib Design, and genotypic variability and gene loss with long term selection. The designs were evaluated by simulation, based on average estimated gains after ten selection cycles. The simulation process was based on seven gene systems with ten genes (with distinct degrees of dominance), three population classes (with different gene frequencies), under three environmental conditions (heritability values), and four selection strategies. Each combination was repeated ten times, amounting to 25, 200 simulations. Full-sib selection is generally more efficient than half-sib selection, mainly with favorable dominant genes. The use of full-sib families derived by Design I is generally more efficient than using progenies obtained by Full-Sib Design. Using Design I with 50 males and 200 females (effective size of 160) did not result in improved populations with minimum genotypic variability. In the populations with lower effective size (160 and 400) the loss of favorable genes was restricted to recessive genes with reduced frequencies.
\end{abstract}

Index terms: Design I, full-sib families, half-sib families, tandem selection, genetic gains.

\section{Estratégias de melhoramento para seleção recorrente com milho}

Resumo - Os objetivos deste trabalho foram analisar ganhos genéticos teóricos de milho como resultado da seleção entre famílias de irmãos completos e de meios-irmãos, obtidas pelos Delineamentos I, de Irmãos Completos e de Meios-Irmãos, e a variabilidade genotípica e perda de genes com seleção a longo prazo. Os delineamentos foram avaliados por simulação, com base nos ganhos médios estimados após dez ciclos de seleção. O processo de simulação considerou sete sistemas gênicos com dez genes (com distintos graus de dominância), três classes de populações (com diferentes freqüências gênicas), sob três condições de ambiente (valores de herdabilidade), e quatro estratégias de seleção. Cada combinação foi repetida dez vezes, totalizando 25.200 simulações. Seleção entre famílias de irmãos completos é geralmente mais eficiente do que seleção com base em progênies de meiosirmãos. Empregar famílias de irmãos completos obtidas pelo Delineamento I é geralmente mais eficiente que usar progênies derivadas do Delineamento de Irmãos Completos. O Delineamento I, com 50 machos e 200 fêmeas (tamanho efetivo de 160), não determinou população melhorada com variabilidade genotípica mínima. Nas populações melhoradas com menor tamanho efetivo (160 e 400), a perda de genes favoráveis é restrita àqueles recessivos em baixa frequiência.

Termos para indexação: Delineamento I, famílias de irmãos completos, famílias de meios-irmãos, seleção em tandem, ganhos genéticos.

\section{Introduction}

Half-sib and full-sib families have been used and proved effective in the improvement of maize populations (Hallauer \& Miranda Filho, 1988). Theoretically, full-sib selection is more efficient than half-sib selection, due to the better parental control. Consequently, predicted gains due to selection are higher. Nevertheless, owing to the possibility of exploiting a greater effective population size with greater ease of operation, half-sib selection is the common procedure.
The Design I, proposed by Comstock \& Robinson (1948), has been commonly used to obtain estimates of the components of genotypic variance (Gouesnard \& Gallais, 1992; Almirall et al., 1996; Mas et al., 1998; Smith et al., 1998; Pereira \& Amaral Júnior, 2001; Ortiz \& Golmirzaie, 2002), but it is not employed as genetic design in recurrent selection programs. A recent exception is the work of Gonçalves et al. (2007) with yellow passion fruit. Their objective was to evaluate alternative strategies of progeny selection for obtaining the best predicted genetic gain. The 
superior strategies were combined selection and halfsib selection.

Melchinger et al. (2003) employed Design I as part of a study on the influence of recombination in two maize parent populations on the means and combining ability variances of their interpopulacional hybrid. They verified different types of epistasis and changes in combining ability variances related to grain yield, dry matter concentration and plant height. Following the same objective, Badu-Apraku et al. (2004) estimated genetic variances and covariances of the maize population Pool 16 DT, from progenies derived by Design I. They verified strong family $x$ environment interaction, since the estimates of genetic parameters varied in magnitude, and some components of genotypic variance were negative. Revilla et al. (2004) developed families from a maize synthetic, following Design I. Their objective was to assess genetic variability of timing for the transition from juvenile to adult vegetative phases. The analyses showed significant additive variance, no interaction with environment and high heritabilities.

The Design I has the drawbacks of frequently negative variance estimates, mainly dominance variance, as well as inaccuracy in the estimation of the dominance variance (Comstock \& Robinson, 1948; Bridges \& Knapp, 1987). The main reasons for negative variances can be inadequate use of the experimental design, an unfit sampling system, inaccurate ranking of the crosses, and insufficient number of females per male (Márquez-Sánchez \& Hallauer, 1970a, 1970b; Bridges \& Knapp, 1987). Márquez-Sánchez \& Hallauer (1970a, 1970b) crossed groups with different numbers of males $(8,16,32$ and 48) with a constant number of females, and different groups of females $(2,4,6,8$, and 10) with a constant number of males. They concluded that six to eight females per male and a minimum number of 48 males would be adequate for an accurate estimation of genetic variance components for the trait grain yield in maize (of low heritability), and that a sample size of approximately 200 plants would be sufficient to estimate genetic parameters.

The objectives of this study were to analyze theoretical genetic gains of maize due to recurrent selection among full-sib and half-sib families, obtained by Design I, Full-Sib Design and Half-Sib Design, and genotypic variability and gene loss with long term selection.

\section{Material and Methods}

The relative merit of three genetic designs in recurrent selection programs with maize was evaluated based on average estimated genetic gain, after ten cycles, obtained by simulations. The simulations considered seven generic traits, three classes of populations, three environmental conditions and four selection strategies. The traits were characterized by different degrees of dominance: 2 and -2 (overdominance), 1 and -1 (complete dominance), $1 / 2$ and $-1 / 2$ (partial dominance) and 0 (absence of dominance). A positive degree of dominance corresponded to a dominant favorable gene (admittedly the one that increases the trait expression), while a negative value expressed a recessive favorable gene. The gene systems assumed ten genes with assortative distribution, absence of epistasis, HardyWeinberg equilibrium and linkage equilibrium.

Since the frequencies of the favorable genes in a population can assume infinite values between 0 and 1 , it was tried to represent all possible populations in three classes. To represent an unimproved population it was assumed that the frequency of six of the favorable genes was 0.1 , the frequency of three was 0.5 , and the frequency of one was 0.9 . To represent populations with intermediate frequencies of favorable genes it was assumed that the frequency of three of the ten was 0.4 , the frequency of five was 0.5 and the frequency of two was 0.6 . To characterize an improved population it was assumed that the frequency of one favorable gene was 0.1 , the frequency of three was 0.5 and the frequency of six was 0.9 .

The experimental conditions or degree of error control varied as well, which resulted in changes in the parametric value of the broad-sense heritability, through the magnitude of the introduced environmental effects. In this way, situations of high (90\%), intermediate (50\%) and low $(10 \%)$ heritability were taken into consideration. Owing to the problem of establishing exactly the desired heritability value, a variation of plus-minus $1 \%$ of the desired value was allowed.

The genetic designs were Design I, Full-Sib Design (a variation of Design I, with one female by male) and Half-Sib Design (another variation of Design I, with males within females). With Design I the simulation process assumed 50 males and 200 females (four females by male). This implied an effective population size of 160 (Krow \&Kimura, 1970). With Full-Sib Design the simulation process assumed 200 males and 
200 females. The effective population size in this case was 400 . With Half-Sib Design the simulation process assumed 200 females and infinite male gametic pool. In this case the effective population size was approximately 800 . The expenses of the breeding processes were fixed by selecting 200 progenies by cycle.

The simulation assumed completely randomized blocks design, two replications and 25 plants by plot. Using the average phenotypic values of progenies, the best $20(10 \%)$ were selected, aiming at recombination. In relation to recombination plots the simulation process assumed parental control equal to 1 (recombination of selected families only), 100 plants in each female line and an infinite male gametic pool. The improved population was obtained without selection in the recombination plot. In the case of Design I, a second among selection strategy was tandem selection selection of the 20 best half-sib progenies ( $40 \%$ ) followed by selection of the best full-sib family in each $(25 \%)$. The genetic gain by selection among families was calculated by the difference between the parametric mean of the improved population (cycle $\mathrm{n}+1)$ and the mean of the previous population (cycle n), and it was expressed as percentage of the mean of the previous population, as follows (Hallauer \& Miranda Filho, 1988):

$$
\Delta M=\frac{2 \sum_{i=1}^{10}\left\{\left(p_{i}^{\prime}-p_{i}\right) a_{i}+\left(p_{i}^{\prime} q_{i}^{\prime}-p_{i} q_{i}\right) d_{i}\right\}}{\sum_{i=1}^{10}\left\{m_{i}+\left(p_{i}-q_{i}\right) a_{i}+2 p_{i} q_{i} d_{i}\right\}} \cdot 100
$$

where, for each gene, p' and $p$ are the frequencies at cycles $n+1$ and $n$ of the gene that increase trait expression; $m$ is the mean of the genotypic values of the homozygotes; $a$ is the deviation between the genotypic value of the homozygote of greatest expression and $\mathrm{m}$; and $\mathrm{d}$ is the deviation due to dominance.

The simulations were made using Microsoft Excel workbook, with many of its built-in functions. The sequence of events were: (1) specification of the trait and of the favorable genes effects, inserting the values of dominance degree (the same for each gene); (2) characterization of the population, inserting the favorable gene frequencies; (3) specification of the environmental conditions, defining the desired heritability; (4) computation of the parametric population mean (cycle 0); (5) simulation of the parents (of females and males in the cases of Design I and Full-Sib Design, and of females in the case of Half-Sib Design) and plant genotypes (150 for each progeny); (6) simulation of the genotypic values, environmental effects and phenotypic values of the plants in each family; (7) analysis of variance of the plot phenotypic values (mean phenotypic value of 25 plants); (8) estimation of genetic parameters (additive and due to dominance genetic variances, and heritabilities) and prediction of gains; (9) identification of the superior families, taking into account the selection unit and the selection strategy; (10) computation of the gene frequencies in the recombination plot, the same of the improved population (cycle 1); and (11) computation of the improved population mean and of estimated gain (first cycle).

For subsequent cycles the same order of steps were taken, except steps (1) and (3). Note the correspondence between steps (10) and (11) - for cycle $\mathrm{n}$ - with steps (2) and (4) - for cycle $n+1$.

Each combination of trait (7), population (3), heritability (3), selection unit/selection strategy (4) - half-sib selection, full-sib selection; full-sib selection derived by Design I and tandem selection - and cycles (10) was replicated ten times, totaling 25,200 simulations.

\section{Results and Discussion}

Although obtained by simulation assuming gene systems with only ten genes, absence of epistasis and linkage equilibrium, the mean values of estimated gains (Tables 1, 2 and 3) are consistent with experimental results with maize and other species of plants and animals. Considering the gene system determining maize grain yield, the average degree of dominance was estimated at 1.64 by Robinson et al. (1949), 1.96 by Cockerham \& Zeng (1996) and 2.57 by Edwards \& Lamkey (2002). In view of the high standard deviations associated with these estimates (Comstock \& Robinson, 1948), overdominance and complete dominance can be assumed in this system. The favorable genes are dominant, due to the positive heterosis in all studies, as in Bordallo et al. (2005).

In the cases of overdominance and complete dominance with favorable dominant genes, the mean annual estimated gains varied from $0.37 \%$ to $3.05 \%$ (mean of $1.30 \%$ ), and from 0.64 to $3.35 \%$ (mean of $1.60 \%$ ) (Table 1). The lowest values were the result of half-sib selection (families obtained by Half-Sib Design) in populations with intermediate gene frequency or improved populations. In an improved population the 
theoretically gains are of small magnitude, due to the narrowed effects of gene substitution (Hallauer \& Miranda Filho, 1988). The highest values, also theoretically expected due to stronger effects of gene substitution (Hallauer \& Miranda Filho, 1988), are the results of full-sib selection in unimproved populations. The gains in grain yield in a single cycle, estimated by Granate et al. (2002) with half-sib families, by Pereira \& Amaral Júnior (2001) with progenies of half-sibs and of full-sibs derived by the use of Design I, and by Daros et al. (2002) with full-sib families obtained by Full-Sib Design were $4.22,6.26$ and 9.42 , and $4.70 \%$, respectively. The means of the estimated gains in the first two cycles (Table 2) through half-sib and full-sib selections, assuming overdominance and complete dominance, favorable dominant genes and unimproved populations, were 4.75 and $6.13 \%$ (6.39, 6.23 and $5.79 \%$ in the cases of selection among progenies derived by Full-Sib Design, of selection among families obtained by Design I and of tandem selection, respectively). Results with long term selection were obtained by Carvalho et al. (2003). Based in 13 cycles of half-sib selection considering grain or ear weight they verified reduction in the additive genetic variance after the first three cycles, associated with a predicted mean gain of $10.60 \%$. The expected and estimated mean gains between cycles six and 15 were 20.00 and $4.03 \%$, associated with a mean heritability of $52.02 \%$. Assuming an unimproved population and overdominance/complete dominance, the mean estimated gain obtained by simulation was $2.81 \%$.

Apart from only two exceptions in 18 simulations, regarding traits such as maize grain yield, the population improvement based on full-sib families was more efficient than improvement based on half-sib progenies. The mean estimated gain through full-sib selection was, at least, by $5.1 \%$ higher than that obtained with half-sib selection in the case of complete dominance, an unimproved population and low heritability. The highest predominance was $70.8 \%$, assuming overdominance, population with intermediate gene frequencies and high heritability. In general, the mean estimated gain through selection using full-sib families was $19.6 \%$ higher than with half-sib progenies ( $25.4 \%$ with overdominance and $13.8 \%$ with complete dominance) (Table 1).

Table 1. Mean values of estimated gains (\%) after ten simulated selection cycles, assuming overdominance $(\mathrm{d} / \mathrm{a}=2$ and -2$)$ and complete dominance $(\mathrm{d} / \mathrm{a}=1 \text { and }-1)^{(1)}$.

\begin{tabular}{|c|c|c|c|c|c|c|c|c|c|}
\hline \multirow[t]{4}{*}{ Population } & \multirow{4}{*}{$\begin{array}{l}\mathrm{h}^{2} \\
(\%)\end{array}$} & \multicolumn{8}{|c|}{ Selection strategy } \\
\hline & & \multicolumn{2}{|c|}{ FS selection } & \multicolumn{2}{|c|}{ FS selection Design I } & \multicolumn{2}{|c|}{ Tandem selection } & \multicolumn{2}{|c|}{ HS selection } \\
\hline & & \multicolumn{2}{|c|}{ Degree of dominance } & \multicolumn{2}{|c|}{ Degree of dominance } & \multicolumn{2}{|c|}{ Degree of dominance } & \multicolumn{2}{|c|}{ Degree of dominance } \\
\hline & & 2 & -2 & 2 & -2 & 2 & -2 & 2 & -2 \\
\hline \multirow[t]{3}{*}{ Unimproved } & 10 & 2.417 & 2.288 & 2.382 & 2.892 & 2.466 & 2.849 & 2.261 & 2.655 \\
\hline & 50 & 2.988 & 3.210 & 2.966 & 3.196 & 2.946 & 3.219 & 2.670 & 3.162 \\
\hline & 90 & 3.033 & 3.280 & 3.030 & 3.426 & 3.048 & 3.264 & 2.672 & 3.010 \\
\hline \multirow{3}{*}{$\begin{array}{l}\text { Intermediate gene } \\
\text { frequencies }\end{array}$} & 10 & 0.593 & 4.456 & 0.543 & 4.836 & 0.604 & 4.486 & 0.488 & 5.112 \\
\hline & 50 & 0.618 & 6.295 & 0.637 & 6.237 & 0.646 & 6.044 & 0.411 & 6.693 \\
\hline & 90 & 0.624 & 6.570 & 0.638 & 6.770 & 0.644 & 6.777 & 0.372 & 7.271 \\
\hline \multirow[t]{4}{*}{ Improved } & 10 & 0.565 & 2.222 & 0.568 & 2.305 & 0.558 & 2.126 & 0.574 & 1.895 \\
\hline & 50 & 0.649 & 2.787 & 0.648 & 2.734 & 0.665 & 2.816 & 0.519 & 2.674 \\
\hline & 90 & 0.650 & 2.595 & 0.635 & 2.748 & 0.612 & 2.372 & 0.490 & 2.643 \\
\hline & & 1 & -1 & 1 & -1 & 1 & -1 & 1 & -1 \\
\hline \multirow[t]{3}{*}{ Unimproved } & 10 & 1.875 & 2.304 & 2.369 & 2.182 & 2.299 & 2.156 & 2.075 & 1.681 \\
\hline & 50 & 3.177 & 3.857 & 3.116 & 3.425 & 3.109 & 2.842 & 2.950 & 2.847 \\
\hline & 90 & 3.351 & 4.390 & 3.335 & 4.582 & 3.332 & 4.055 & 3.160 & 4.116 \\
\hline \multirow{3}{*}{$\begin{array}{l}\text { Intermediate gene } \\
\text { frequencies }\end{array}$} & 10 & 1.041 & 3.448 & 1.034 & 3.494 & 1.094 & 3.214 & 0.933 & 3.127 \\
\hline & 50 & 1.307 & 4.350 & 1.336 & 4.502 & 1.366 & 4.366 & 1.102 & 4.496 \\
\hline & 90 & 1.383 & 4.452 & 1.412 & 4.512 & 1.430 & 4.704 & 1.110 & 4.728 \\
\hline \multirow[t]{3}{*}{ Improved } & 10 & 0.699 & 1.694 & 0.714 & 1.757 & 0.682 & 1.622 & 0.641 & 1.449 \\
\hline & 50 & 0.816 & 2.136 & 0.793 & 2.051 & 0.797 & 1.834 & 0.713 & 1.858 \\
\hline & 90 & 0.838 & 2.343 & 0.831 & 2.363 & 0.834 & 2.390 & 0.670 & 2.179 \\
\hline
\end{tabular}

${ }^{(1)} \mathrm{h}^{2}(\%)=$ heritability; FS = full-sib; HS = half-sib. 
Among the selection procedures with full-sib families none was clearly superior to others, for traits such as maize grain yield. In seven of the 18 simulations the highest mean estimated gains were obtained with selection among full-sib progenies derived by Design I; in six, highest values were obtained with tandem selection; in the other five simulations, with selection among families derived by Full-Sib Design. The differences among mean gains were generally of small magnitude, between 1 and $6 \%$ (4.8\% on the average; $3.9 \%$ with overdominance and $5.7 \%$ with complete dominance) (Table 1).

Robinson et al. (1949) and Cockerham \& Zeng (1996) obtained results with maize that indicate partial dominance and absence of dominance in the gene systems that control the traits plant height, ear height, number of ears, prolificacy, number of kernel rows per ear, and weight of 500 grains. The gains estimated in these studies are however indirect and therefore unsuitable for a comparison with the gains estimated here.

Considering positive partial dominance and absence of dominance, also in 16 of 18 simulations, the mean estimated gains were lower with half-sib selection, in comparison with selection based on full-sib progenies (Table 3). Compared to the mean estimated gain through half-sib selection, the overall mean of the mean estimated gains with full-sib selection was at least $0.8 \%$ higher with no dominance. The maximum efficiency, in absence of dominance as well, was $35.2 \%$ (overall mean value of $11.7 \%$; on average $9.6 \%$ with partial dominance and $13.8 \%$ without dominance) (Table 3 ). Therefore, the efficiency of selection based on full-sib families tends to be greater, the higher the degree of dominance of the favorable genes.

In contrast to the results with overdominance and complete dominance, with favorable dominant genes, higher estimated gains through selection were obtained with selection among full-sib families derived by Design I in the cases of partial dominance with favorable dominant genes and absence of dominance, compared to the other selection procedures based on full-sib progenies. In 10 of the 18 simulations the highest mean estimated gains were obtained with selection among full-sib progenies derived by Design I; in five, with tandem selection; in the other three simulations the highest gains were obtained with selection among families obtained by Full-Sib Design. The greatest differences between mean estimated gains with full-sib selection varied from 0.4 to $17.5 \%$ in the absence of dominance (mean of $7 \%$ ), and from 1.1 to $6.8 \%$ with partial dominance (mean of $8.2 \%$ ), with an average of $7.6 \%$ (Table 3 ).

In the case of selection for favorable recessive genes, half-sib selection is not always the least efficient

Table 2. Mean values of estimated gains $(\%)$ in the first two simulated selection cycles, assuming dominant favorable genes ${ }^{(1)}$.

\begin{tabular}{|c|c|c|c|c|c|c|c|c|c|c|}
\hline \multirow[t]{3}{*}{ Population } & \multirow{3}{*}{$\begin{array}{c}\mathrm{h}^{2} \\
(\%)\end{array}$} & \multirow[t]{3}{*}{$\mathrm{d} / \mathrm{a}$} & \multicolumn{8}{|c|}{ Selection strategy } \\
\hline & & & \multicolumn{2}{|c|}{ FS sel. } & \multicolumn{2}{|c|}{ FS sel. DI } & \multicolumn{2}{|c|}{ Tandem sel. } & \multicolumn{2}{|c|}{ HS sel. } \\
\hline & & & 1 & 2 & 1 & 2 & 1 & 2 & 1 & 2 \\
\hline \multirow[t]{3}{*}{ Unimproved } & 10 & 2 & 2.663 & 5.931 & 0.519 & 4.608 & 4.725 & 4.753 & 1.401 & 2.016 \\
\hline & 50 & 2 & 7.618 & 6.431 & 12.671 & 7.611 & 6.283 & 4.034 & 6.761 & 6.566 \\
\hline & 90 & 2 & 9.693 & 8.383 & 9.256 & 7.063 & 10.385 & 8.680 & 8.419 & 5.630 \\
\hline \multirow[t]{3}{*}{ Intermediate gene frequencies } & 10 & 2 & 1.037 & 0.411 & 1.754 & 1.328 & 0.519 & 4.608 & 1.971 & 0.232 \\
\hline & 50 & 2 & 3.405 & 1.273 & 3.409 & 0.204 & 2.026 & 1.839 & 2.193 & 0.790 \\
\hline & 90 & 2 & 3.938 & 1.352 & 2.856 & 1.073 & 2.269 & 2.455 & 2.086 & 0.781 \\
\hline \multirow[t]{3}{*}{ Improved } & 10 & 2 & 2.662 & 0.569 & 1.856 & 0.154 & 3.294 & 4.330 & 1.687 & 0.476 \\
\hline & 50 & 2 & 2.316 & 2.786 & 0.877 & 3.314 & 10.009 & 3.900 & 1.934 & 1.143 \\
\hline & 90 & 2 & 3.149 & 2.192 & 0.877 & 3.314 & 7.410 & 5.861 & 2.450 & 1.430 \\
\hline \multirow[t]{3}{*}{ Unimproved } & 10 & 1 & 4.065 & 2.423 & 1.201 & 2.912 & 2.040 & 4.090 & 1.733 & 3.126 \\
\hline & 50 & 1 & 6.204 & 6.155 & 5.884 & 6.269 & 7.100 & 3.852 & 4.455 & 4.374 \\
\hline & 90 & 1 & 9.644 & 7.459 & 7.289 & 9.442 & 7.087 & 6.412 & 6.103 & 6.429 \\
\hline \multirow[t]{3}{*}{ Intermediate gene frequencies } & 10 & 1 & 1.280 & 3.301 & 2.028 & 3.078 & 0.976 & 1.405 & 1.075 & 1.824 \\
\hline & 50 & 1 & 4.549 & 2.290 & 4.284 & 2.892 & 5.720 & 1.596 & 3.381 & 1.559 \\
\hline & 90 & 1 & 6.462 & 2.824 & 4.919 & 3.738 & 5.868 & 3.631 & 3.982 & 2.782 \\
\hline \multirow[t]{3}{*}{ Improved } & 10 & 1 & 1.614 & 1.331 & 0.266 & 0.809 & 1.483 & 0.994 & 1.407 & 1.136 \\
\hline & 50 & 1 & 2.328 & 1.703 & 2.641 & 2.194 & 2.572 & 0.937 & 1.776 & 1.275 \\
\hline & 90 & 1 & 2.955 & 2.460 & 3.035 & 2.593 & 2.757 & 2.278 & 2.915 & 1.613 \\
\hline
\end{tabular}

${ }^{(1)} \mathrm{h}^{2}(\%)=$ heritability; $\mathrm{d} / \mathrm{a}=$ degree of dominance; FS = full-sib; HS = half-sib. 
procedure, compared to selection based on full-sib progenies. In 14 of the 27 simulations that included overdominance, complete dominance and partial dominance, the lowest mean gain was obtained though half-sib selection (Tables 1 and 3). The mean estimated gain through full-sib selection exceeded the gain through half-sib selection by up to $32.5 \%$, with a minimum of $0.6 \%$ and mean of $11.6 \%$. In the cases where the mean estimated gain through half-sib selection exceeded the mean gain through full-sib selection, the minimum, average and maximum values were 2, 5.1 and $10.2 \%$, respectively (Tables 1 and 3). The selection for recessive favorable genes confirmed once more the superiority of the selection among full-sib progenies obtained by Design I, compared to the other two selection strategies among full-sib families. In 14 of the 27 evaluated situations, the highest mean estimated gains were obtained through selection among full-sib families derived by Design I; in seven, the highest values were obtained with tandem selection; in the other six situations, through selection among progenies obtained by Full-Sib Design. The difference in mean estimated gain between the selection strategies varied from 0.7 to $35.7 \%$, with an average of 9\% (Tables 1 and 3).
The results of the mean estimated gains reported for each cycle (Tables 1,2 and 3) are consistent with the theory of Quantitative Genetics, giving credibility to the simulated data. The conditions were therefore adequate for an evaluation of the efficiency of the selection procedures under study. Independently of the trait, of the improvement level of the reference population and of the selection strategy, gains were proportional to their heritability. Even in the condition of low heritability, all selection procedures promote population improvement. The mean gain associated with the initial heritability of 0.1 was $1.92 \%$ and rose to 2.63 and $2.84 \%$ when the heritability was 0.5 and 0.9 . Invariably, the analysis of the gains per cycle indicated higher gains in the early cycles and gradual reduction thereafter. The gains were inversely proportional to the improvement degree of the population. The gains were also proportional to the degree of dominance; they were lower with overdominance and favorable dominant genes and higher with overdominance and favorable recessive genes. With favorable dominant genes and no dominance, mean gains were higher when the base population was unimproved, independently of the heritability and selection strategy. The same was true for traits determined by favorable recessive genes. With overdominance and

Table 3. Mean values of estimated gains (\%) after ten simulated selection cycles, assuming partial dominance $(\mathrm{d} / \mathrm{a}=1 / 2$ and $-1 / 2)$ and absence dominance $(\mathrm{d} / \mathrm{a}=0)^{(1)}$.

\begin{tabular}{|c|c|c|c|c|c|c|c|c|c|}
\hline \multirow[t]{4}{*}{ Population } & \multirow[t]{4}{*}{$h^{2}(\%)$} & \multicolumn{8}{|c|}{ Selection strategy } \\
\hline & & \multicolumn{2}{|c|}{ FS selection } & \multicolumn{2}{|c|}{ FS selection Design I } & \multicolumn{2}{|c|}{ Tandem selection } & \multicolumn{2}{|c|}{ HS selection } \\
\hline & & \multicolumn{2}{|c|}{ Degree of dominance } & \multicolumn{2}{|c|}{ Degree of dominance } & \multicolumn{2}{|c|}{ Degree of dominance } & \multicolumn{2}{|c|}{ Degree of dominance } \\
\hline & & $1 / 2$ & $-1 / 2$ & $1 / 2$ & $-1 / 2$ & $1 / 2$ & $-1 / 2$ & $1 / 2$ & $-1 / 2$ \\
\hline \multirow[t]{3}{*}{ Unimproved } & 10 & 1.758 & 2.247 & 2.713 & 2.345 & 2.256 & 1.914 & 2.146 & 1.909 \\
\hline & 50 & 3.548 & 4.285 & 3.574 & 4.054 & 3.640 & 4.307 & 3.284 & 3.181 \\
\hline & 90 & 3.840 & 4.650 & 3.815 & 4.654 & 3.741 & 4.543 & 4.283 & 4.720 \\
\hline Intermediate gene & 10 & 1.532 & 2.733 & 1.637 & 2.797 & 1.569 & 2.522 & 1.281 & 2.405 \\
\hline \multirow[t]{2}{*}{ frequencies } & 50 & 1.978 & 3.593 & 2.014 & 3.616 & 1.983 & 3.497 & 1.768 & 3.531 \\
\hline & 90 & 2.117 & 3.699 & 2.163 & 3.806 & 2.128 & 3.675 & 1.885 & 3.706 \\
\hline \multirow[t]{3}{*}{ Improved } & 10 & 0.954 & 1.486 & 0.951 & 1.418 & 0.942 & 1.421 & 0.884 & 1.211 \\
\hline & 50 & 1.196 & 1.891 & 1.208 & 1.933 & 1.193 & 1.982 & 1.047 & 1.669 \\
\hline & 90 & 1.229 & 2.063 & 1.237 & 2.038 & 1.243 & 1.910 & 1.096 & 1.865 \\
\hline \multirow{4}{*}{ Unimproved } & & \multicolumn{2}{|c|}{0} & \multicolumn{2}{|c|}{0} & \multicolumn{2}{|c|}{0} & \multicolumn{2}{|c|}{0} \\
\hline & 10 & \multicolumn{2}{|c|}{2.451} & \multicolumn{2}{|c|}{2.552} & \multicolumn{2}{|c|}{2.285} & \multicolumn{2}{|c|}{1.934} \\
\hline & 50 & \multicolumn{2}{|c|}{3.876} & \multicolumn{2}{|c|}{3.907} & \multicolumn{2}{|c|}{3.610} & \multicolumn{2}{|c|}{3.448} \\
\hline & 90 & \multicolumn{2}{|c|}{4.336} & \multicolumn{2}{|c|}{4.308} & \multicolumn{2}{|c|}{4.301} & \multicolumn{2}{|c|}{4.279} \\
\hline \multirow{3}{*}{$\begin{array}{l}\text { Intermediate gene } \\
\text { frequencies }\end{array}$} & 10 & \multicolumn{2}{|c|}{2.146} & & & & & & \\
\hline & 50 & & & & & & & & \\
\hline & 90 & & & & & & & & \\
\hline Improved & 10 & & & & & & & & \\
\hline & 50 & & & & & & & & \\
\hline & 90 & & & & & & & & \\
\hline
\end{tabular}

${ }^{(1)} h^{2}(\%)=$ heritability; FS = full-sib; HS = half-sib. 
complete dominance but favorable recessive genes, mean gains were higher when the base population had intermediate gene frequencies.

Independent of the degree of population improvement, of the trait and of the heritability, the efficiency in promoting improvement was greater when full-sib families were used, compared to half-sib progenies. The superiority of the selection among full-sib progenies obtained by Design I, compared to half-sib selection varied from 4.5 to $12.2 \%$ ( $8.3 \%$ in the mean), depending on the degree of population improvement, or from 4.3 to $16.6 \%$ (10.7\% in the mean), depending on the trait, or from 4.1 to $15.1 \%$ (9.5\% in the mean), depending on the heritability. Although the differences were not very large, it was more efficient to use full-sib families derived by Design I than progenies obtained by Full-sib Design. The mean estimated gain in the first case was by 2.5 to $3.0 \%$ higher than in the second. In summary, in the long term all selection procedures, including mass selection, lead to the same level of population improvement.

For the genotypic variability in the population after 10 cycles, considering again a trait such as maize grain yield, determined by a gene system with overdominance and complete dominance, with favorable dominant genes, there was no evidence of greater variability associated with the population of largest effective size (Table 4). In only three of the 18 simulations the population with greatest variability was the one obtained with half-sib selection, of largest effective size (800). In spite of the smaller effective size (160), the population under selection among full-sib progenies derived by Design I generally presented the highest value of genotypic variance (Table 4). The analysis of traits determined by partially dominant favorable genes or without dominance, evidenced a greater variability in populations obtained by half-sib selection in eight of the 18 situations under study. Among the strategies based on full-sib progenies, the population of greatest genotypic variability resulted from tandem selection (Table 5). In relation to traits determined by favorable recessive genes, it may be concluded that the population obtained by half-sib selection tends to have a greater genotypic variability than the ones derived by full-sib selection. This was the case in 15 of the 18 simulations (Tables 4 and 5). Nevertheless, the lowest variability was not systematically associated with the population of smallest effective size, subjected to selection among full-sib progenies obtained by Design I, including tandem selection.

In an additional evaluation of the selection procedures regarding the loss of favorable genes by genetic drift, the analysis of gene frequencies per selection cycle in the different replications showed the following (Table 6): there was only random loss of favorable recessive genes

Table 4. Mean relative values of genotypic variance (\%) after ten selection cycles, for different selection strategies ${ }^{(1)}$.

\begin{tabular}{|c|c|c|c|c|c|c|c|c|c|c|}
\hline \multirow[t]{2}{*}{ Population } & \multirow[t]{2}{*}{$h^{2}(\%)$} & \multirow[t]{2}{*}{ Favorable gene } & \multicolumn{4}{|c|}{ Overdominance } & \multicolumn{4}{|c|}{ Complete dominance } \\
\hline & & & FS sel. & FS sel. DI & Tandem sel. & HS sel. & FS sel. & FS sel. DI & Tandem sel. & HS sel. \\
\hline \multirow[t]{3}{*}{ Unimproved } & 10 & Dominant & 100.0 & 109.9 & 112.7 & 105.6 & 100.0 & 111.5 & 111.7 & 115.7 \\
\hline & 50 & Dominant & 102.3 & 100.0 & 116.4 & 117.2 & 100.0 & 108.5 & 123.8 & 127.5 \\
\hline & 90 & Dominant & 106.6 & 100.1 & 138.6 & 100.0 & 100.0 & 117.1 & 130.6 & 118.2 \\
\hline \multirow{3}{*}{$\begin{array}{l}\text { Intermediate gene } \\
\text { frequencies }\end{array}$} & 10 & Dominant & 107.3 & 100.0 & 106.9 & 106.1 & 106.9 & 100.0 & 133.2 & 128.6 \\
\hline & 50 & Dominant & 101.6 & 108.0 & 131.2 & 100.0 & 108.2 & 106.1 & 113.1 & 100.0 \\
\hline & 90 & Dominant & 111.2 & 125.1 & 116.0 & 100.0 & 100.0 & 142.6 & 134.6 & 126.7 \\
\hline \multirow[t]{3}{*}{ Improved } & 10 & Dominant & 109.1 & 123.0 & 116.1 & 100.0 & 100.0 & 114.8 & 104.3 & 112.9 \\
\hline & 50 & Dominant & 109.5 & 121.8 & 100.0 & 115.5 & 111.9 & 125.8 & 113.8 & 100.0 \\
\hline & 90 & Dominant & 108.3 & 108.2 & 104.2 & 100.0 & 121.4 & 124.1 & 110.1 & 100.0 \\
\hline \multirow[t]{3}{*}{ Unimproved } & 10 & Recessive & 113.4 & 100.0 & 102.0 & 124.3 & 104.5 & 113.5 & 100.0 & 125.9 \\
\hline & 50 & Recessive & 107.7 & 100.0 & 117.8 & 140.0 & 102.4 & 113.4 & 100.0 & 114.7 \\
\hline & 90 & Recessive & 100.0 & 139.3 & 128.5 & 182.1 & 100.0 & 134.8 & 147.0 & 142.9 \\
\hline \multirow{3}{*}{$\begin{array}{l}\text { Intermediate gene } \\
\text { frequencies }\end{array}$} & 10 & Recessive & 100.0 & 107.5 & 121.3 & 143.4 & 100.0 & 112.1 & 103.0 & 140.0 \\
\hline & 50 & Recessive & 100.0 & 118.2 & 125.8 & 127.6 & 100.0 & 106.7 & 105.9 & 133.2 \\
\hline & 90 & Recessive & 100.0 & 119.3 & 135.3 & 182.9 & 115.9 & 100.0 & 116.3 & 140.6 \\
\hline \multirow[t]{3}{*}{ Improved } & 10 & Recessive & 111.1 & 117.0 & 100.0 & 123.0 & 100.0 & 115.4 & 107.6 & 119.5 \\
\hline & 50 & Recessive & 103.4 & 116.6 & 100.0 & 134.6 & 108.7 & 100.0 & 133.5 & 124.9 \\
\hline & 90 & Recessive & 116.7 & 100.0 & 161.8 & 142.2 & 114.0 & 100.0 & 124.1 & 169.5 \\
\hline
\end{tabular}

${ }^{(1)} h^{2}(\%)=$ heritability; FS = full-sib; HS = half-sib. 
Table 5. Mean relative values of genotypic variance (\%) after ten selection cycles, for different selection strategies ${ }^{(1)}$.

\begin{tabular}{|c|c|c|c|c|c|c|c|c|c|c|}
\hline \multirow[t]{2}{*}{ Population } & \multirow{2}{*}{\multicolumn{2}{|c|}{$\mathrm{h}^{2}(\%)$ Favorable gene }} & \multicolumn{4}{|c|}{ Partial dominance } & \multicolumn{4}{|c|}{ Absence of dominance } \\
\hline & & & FS sel. & FS sel. DI & Tandem sel. & HS sel. & FS sel. & FS sel. DI & Tandem sel. & HS sel. \\
\hline \multirow{3}{*}{ Unimproved } & 10 & Dominant & 160.9 & 100.0 & 130.9 & 131.1 & 144.0 & 134.0 & 100.0 & 120.1 \\
\hline & 50 & Dominant & 100.0 & 120.4 & 130.3 & 146.5 & 100.0 & 106.1 & 119.3 & 125.5 \\
\hline & 90 & Dominant & 100.0 & 125.8 & 140.7 & 136.6 & 100.0 & 118.8 & 121.1 & 148.8 \\
\hline Intermediate gene & 10 & Dominant & 100.0 & 118.6 & 111.1 & 128.8 & 100.0 & 100.8 & 118.7 & 116.5 \\
\hline \multirow[t]{2}{*}{ frequencies } & 50 & Dominant & 100.0 & 108.5 & 116.0 & 108.8 & 100.0 & 106.0 & 115.3 & 134.4 \\
\hline & 90 & Dominant & 100.0 & 114.9 & 134.4 & 116.0 & 100.0 & 109.1 & 138.1 & 140.1 \\
\hline \multirow[t]{3}{*}{ Improved } & 10 & Dominant & 100.0 & 114.4 & 123.9 & 106.4 & 118.6 & 114.4 & 100.0 & 117.5 \\
\hline & 50 & Dominant & 102.6 & 110.7 & 100.0 & 129.5 & 100.0 & 113.2 & 132.9 & 132.7 \\
\hline & 90 & Dominant & 101.9 & 100.0 & 115.4 & 141.2 & 100.0 & 127.3 & 191.2 & 216.0 \\
\hline \multirow[t]{3}{*}{ Unimproved } & 10 & Recessive & 119.6 & 110.4 & 100.0 & 155.4 & & & & \\
\hline & 50 & Recessive & 114.6 & 120.6 & 100.0 & 131.2 & & & & \\
\hline & 90 & Recessive & 101.3 & 100.0 & 110.1 & 152.8 & & & & \\
\hline \multirow{3}{*}{$\begin{array}{l}\text { Intermediate gene } \\
\text { frequencies }\end{array}$} & 10 & Recessive & 112.0 & 100.0 & 106.3 & 116.0 & & & & \\
\hline & 50 & Recessive & 100.0 & 113.8 & 109.6 & 140.9 & & & & \\
\hline & 90 & Recessive & 100.0 & 132.7 & 162.7 & 159.3 & & & & \\
\hline \multirow[t]{3}{*}{ Improved } & 10 & Recessive & 120.8 & 100.0 & 187.5 & 177.4 & & & & \\
\hline & 50 & Recessive & 120.8 & 100.0 & 108.9 & 151.7 & & & & \\
\hline & 90 & Recessive & 100.0 & 155.1 & 175.5 & 177.6 & & & & \\
\hline
\end{tabular}

${ }^{(1)} \mathrm{h}^{2}(\%)=$ heritability; FS = full-sib; HS = half-sib.

Table 6. Final gene frequencies after ten selection cycles, for different selection strategies, assuming recessive favorable genes $^{(1)}$.

\begin{tabular}{|c|c|c|c|c|c|c|c|c|c|c|c|c|}
\hline \multirow{2}{*}{$\begin{array}{l}\text { Selection } \\
\text { strategy }\end{array}$} & \multirow[t]{2}{*}{$h^{2}(\%)$} & \multirow[t]{2}{*}{$\mathrm{d} / \mathrm{a}$} & \multicolumn{10}{|c|}{ Initial gene frequency } \\
\hline & & & 0.1 & 0.1 & 0.1 & 0.1 & 0.1 & 0.1 & 0.5 & 0.5 & 0.5 & 0.9 \\
\hline \multirow[t]{3}{*}{ FS sel. } & 10 & -2 & 0.000 & 0.186 & 0.000 & 0.000 & 0.024 & 0.000 & 1.000 & 0.962 & 1.000 & 1.000 \\
\hline & 50 & -2 & 0.000 & 0.000 & 0.000 & 0.010 & 0.000 & 0.000 & 1.000 & 1.000 & 1.000 & 1.000 \\
\hline & 90 & -2 & 0.000 & 0.000 & 0.000 & 0.000 & 0.000 & 0.000 & 1.000 & 1.000 & 1.000 & 1.000 \\
\hline \multirow[t]{3}{*}{ FS sel. DI } & 10 & -2 & 0.000 & 0.027 & 0.021 & 0.000 & 0.012 & 0.039 & 1.000 & 0.984 & 0.613 & 1.000 \\
\hline & 50 & -2 & 0.000 & 0.000 & 0.000 & 0.000 & 0.060 & 0.000 & 1.000 & 1.000 & 1.000 & 1.000 \\
\hline & 90 & -2 & 1.000 & 0.000 & 0.000 & 0.000 & 0.000 & 0.000 & 1.000 & 1.000 & 1.000 & 1.000 \\
\hline \multirow[t]{3}{*}{ HS sel. } & 10 & -2 & 0.009 & 0.004 & 0.021 & 0.057 & 0.004 & 0.003 & 0.895 & 0.952 & 0.996 & 0.994 \\
\hline & 50 & -2 & 0.005 & 0.000 & 0.000 & 0.005 & 0.003 & 0.004 & 1.000 & 1.000 & 0.997 & 1.000 \\
\hline & 90 & -2 & 0.000 & 0.001 & 0.000 & 0.000 & 0.000 & 0.001 & 1.000 & 1.000 & 1.000 & 1.000 \\
\hline \multirow[t]{3}{*}{ FS sel. } & 10 & -1 & 0.583 & 0.000 & 0.113 & 0.094 & 0.116 & 0.152 & 0.990 & 1.000 & 1.000 & 1.000 \\
\hline & 50 & -1 & 0.000 & 0.807 & 0.587 & 0.989 & 0.950 & 0.000 & 1.000 & 1.000 & 1.000 & 1.000 \\
\hline & 90 & -1 & 1.000 & 1.000 & 1.000 & 0.644 & 1.000 & 0.064 & 1.000 & 1.000 & 1.000 & 1.000 \\
\hline \multirow[t]{3}{*}{ FS sel. DI } & 10 & -1 & 0.033 & 0.088 & 0.318 & 0.000 & 0.118 & 0.244 & 0.878 & 0.928 & 1.000 & 1.000 \\
\hline & 50 & -1 & 0.000 & 0.948 & 0.990 & 0.901 & 0.032 & 0.201 & 1.000 & 1.000 & 1.000 & 1.000 \\
\hline & 90 & -1 & 0.986 & 0.821 & 0.961 & 1.000 & 0.268 & 0.490 & 1.000 & 1.000 & 1.000 & 1.000 \\
\hline \multirow[t]{3}{*}{ HS sel. } & 10 & -1 & 0.051 & 0.213 & 0.294 & 0.088 & 0.189 & 0.005 & 0.864 & 0.914 & 0.948 & 1.000 \\
\hline & 50 & -1 & 0.448 & 0.700 & 0.134 & 0.261 & 0.085 & 0.150 & 0.999 & 0.997 & 0.995 & 1.000 \\
\hline & 90 & -1 & 0.661 & 0.958 & 0.269 & 0.994 & 0.488 & 0.283 & 1.000 & 1.000 & 1.000 & 1.000 \\
\hline
\end{tabular}

${ }^{(1)} \mathrm{h}^{2}(\%)=$ heritability; d/a = degree of dominance; FS = full-sib; HS = half-sib.

in gene systems with overdominance and occasionally with complete dominance, and in cases of low frequency in the original population (0.1); the loss was most frequent in populations subjected to selection based on full-sib families, certainly due to the smaller effective size (160 and 400); even in populations under half-sib selection an occasional loss of favorable recessive genes at low frequency is possible.

\section{Conclusions}

1. Full-sib selection is generally more efficient than half-sib selection, mainly with favorable dominant genes.

2. The use of full-sib families derived by Design I is generally more efficient than using progenies obtained by Full-Sib Design. 
3. Using Design I with 50 males and 200 females (effective size of 160) does not provide improved populations with minimum genotypic variability.

4. In the populations with lower effective size (160 and 400) the loss of favorable genes is restricted to recessive genes with reduced frequencies.

\section{References}

ALMIRALL, A.; CASAÑAS, F.; BOSCH, L.; SANCHEZ, E.; PEREZ, A.; NUEZ, F. Genetic study of the forage nutritive value in the Lancaster variety of maize. Maydica, v.41, p.227-234, 1996.

BADU-APRAKU, B.; FAKOREDE, M.A.B.; MENKIR, A.; KAMARA, A.Y.; ADAM, A. Effects of drought screening methodology on genetic variances and covariances in Pool 16 DT maize population. Journal of Agricultural Science, v.142, p.445452, 2004

BORDALLO, P.N.; PEREIRA, M.G.; AMARAL JUNIOR, A.T.; GABRIEL, A.P.C. Análise dialélica de genótipos de milho doce e comum para caracteres agronômicos e proteína total. Horticultura Brasileira, v.23, p.123-127, 2005.

BRIDGES JUNIOR, W.C.; KNAPP, S.J. Probabilities of negative estimates of genetic variances. Theoretical and Applied Genetics, v.24, p.269-274, 1987.

CARVALHO, H.W.L.; SANTOS, M.X.; LEAL, M.L.S.; SOUZA, E.M. Estimativas de parâmetros genéticos da variedade BR 5028São Francisco no Nordeste brasileiro. Pesquisa Agropecuária Brasileira, v.38, p.929-935, 2003.

COCKERHAM, C.C.; ZENG, Z.B. Design III with marker loci. Genetics, v.143, p.1437-1456, 1996.

COMSTOCK, R.E.; ROBINSON, H.F. The components of genetic variance in populations of biparental progenies and their use in estimating the average degree of dominance. Biometrics, v.4, p.254266,1948

DAROS, M.; AMARAL JUNIOR, A.T.; PEREIRA, M.G. Genetic gain for grain yield and popping expansion in full-sib recurrent selection in popcorn. Crop Breeding and Applied Biotechnology, v.2, p.339-344, 2002.

EDWARDS, J.W.; LAMKEY, K.R. Quantitative genetics of inbreeding in a synthetic maize population. Crop Science, v.42, p.1094-1104, 2002.

GONÇALVES, G.M.; VIANA, A.P.; BEZERRA, F.V.; PEREIRA, M.G.; PEREIRA, T.N.S. Selection and heritability in the prediction of genetic gain in yellow passion fruit. Pesquisa Agropecuária Brasileira, v.42, p.193-198, 2007.
GOUESNARD, B.; GALLAIS, A. Genetic variance component estimation in a nested mating design with positive assortative mating, and application to maize. Crop Science, v.32, p.11271131, 1992.

GRANATE, M.J.; CRUZ, C.D.; PACHECO, C.A.P. Predição de ganho genético com diferentes índices de seleção no milho pipoca CMS-43. Pesquisa Agropecuária Brasileira, v.37, p.1001-1008, 2002.

HALLAUER, A.R.; MIRANDA FILHO, J.B. Quantitative genetics in plant breeding. $2^{\text {nd }}$ ed. Ames: Iowa State University Press, 1988. 468p.

KROW, J.F.; KIMURA, M. An introduction to population genetics theory. New York: Harper \& Row, 1970. 591p.

MÁRQUEZ-SÁNCHEZ; F.; HALLAUER, A.R. Influence of sample size on the estimation of genetic variances in a synthetic variety of maize. I. Grain yield. Crop Science, v.10, p.357361, 1970a.

MÁRQUEZ-SÁNCHEZ, F.; HALLAUER, A.R. Influence of sample size on the estimation of genetic variances in a synthetic variety of maize. II. Plant and ear characters. Iowa State Journal of Science, v.44, p.423-436, $1970 \mathrm{~b}$.

MAS, M.T.; BOSCH, L.; CASAÑAS, F.; VALERO, J.; NUEZ, F. Semiexotic population of corn Mo17xAcross 8443 La Posta as a base for forage breeding. Maydica, v.43, p.291-300, 1998.

MELCHINGER, A.E.; GEIGER, H.H.; UTZ, H.F.; SCHNELL, F.W. Effect of recombination in the parent populations on the means and combining ability variances in hybrid populations of maize (Zea mays L.). Theoretical and Applied Genetics, v.106, p.332-340, 2003.

ORTIZ, R.; GOLMIRZAIE, A. Hierarchical and factorial mating designs for quantitative genetic analysis in tetrasomic potato. Theoretical and Applied Genetics, v.104, p.675-679, 2002.

PEREIRA, M.G.; AMARAL JUNIOR, A.T. Estimation of genetic components in popcorn based on the nested design. Crop Breeding and Applied Biotechnology, v.1, p.3-10, 2001.

REVILLA, P.; MALVAR, R.A.; BUTRON, A.; TRACY, W.F.; ABEDON, B.G.; ORDAS, A. Genetics of the timing of vegetative phase transition in a maize population. Plant Breeding, v.123, p.585-586, 2004.

ROBINSON, H.F.; COMSTOCK, R.E.; HARVEY, P.H. Estimates of heritability and the degree of dominance in corn. Agronomy Journal, v.41, p.353-359, 1949.

SMITH, S.E.; KUEHL, R.O.; RAY, I.M.; HUI, R.; SOLERI, D. Evaluation of simple methods for estimating broad-sense heritability in stands of randomly planted genotypes. Crop Science, v.38, p.1125-1129, 1998.

Received on May 3, 2007 and accepted on August 6, 2007 